\title{
European Monetary Integration and the EU-UK Relationship
}

To appear in «The Economics of the UK-EU Relationship: From the Treaty of Rome to the Vote for Brexit» by N. Campos and F. Coricelli (Eds.), Palgrave Macmillan

Corrado Macchiarelli

Corrado Macchiarelli is a Lecturer in Economics and Finance at Brunel University London and a Visiting Research Fellow in European Political Economy at the London School of Economics.

"People only accept change when they are faced with necessity, and only recognize necessity when a crisis is upon them" (J. Monnet)

\begin{abstract}
The history of European integration has been characterized by several 'stops-and-goes' with considerable support on political grounds. In this chapter, we discuss the role of European integration for the future of the EU-UK relations. Integration, consistent with the idea of 'completing' the European Monetary Union (hence, a 'Genuine Economic and Monetary Union'- GEMU), will have the obvious consequence of affecting the UK as well and the future of its negotiations with the EU. Provided that European integration worked in the past, the net benefits of staying out of the EU ex-ante may be different from the same benefits expost, particularly in the likely scenario the Union will have to 'comprehensively' move towards a GEMU to safeguard its integrity.
\end{abstract}

\section{Introduction}

The idea of "ever closer" union is ill-defined, owing to the uncertainty that surrounds it. Still, paraphrasing Jean Monnet, Europe always established itself through discrete and evolutionary steps, where the need for more integration, particularly during crises, has met with the majority of political (rather than economic) support. European integration has never been a jump forward all at once: on the contrary, the very limits one stage exposed led - in many instances - to the necessity for the next step. In this context, British attitude towards 
Europe is no exception. While the UK's support has always been volatile and influenced by the particular interests of the country in safeguarding trade and sovereignty (see also Ramiro Troitiño, 2016), the UK-EU relationship has historically been strong and incremental. This suggests that the multi-layer crisis we are living, and, as a consequence the tightening of the UK-EU relations, is not too telling about the $\mathrm{E}(\mathrm{M}) \mathrm{U}$ and the EU-UK relations' future success. The size of the recent crisis may well act as a catalyst for reforms; something not new in the European integration process.

Since the sign up of the Maastricht Treaty, there have not been many 'stops' in European integration, the most severe one being the global economic and financial turmoil taking central stage in Europe. The crisis exposed the inherent "fragility" of the EMU (De Grauwe, 2016a), calling for the need to put in place a framework to deal with the growing imbalances of macro-financial and democratic nature within the monetary union. Since 2010, the exceptional effort that has been put in place has translated into reforms both on the legal and the institutional sides (see ECB, 2011b). Particularly, the creation a new two-pillar system of financial supervision (see de Larosière Group, 2009), i.e. the European System of Financial Supervision (ESFS); the conception of a European liquidity fund, i.e. the European Stability Mechanism; the revamp of macroeconomic policy coordination and fiscal surveillance, i.e. the Fiscal Compact and annex legislations (Two Pack and Six Pack; see ECB, 2010); together with a renovated role for the ECB in financial stability and supervision (see Gerba and Macchiarelli, 2015), including the historic agreement on a banking union for Europe (see Macchiarelli, 2016). These initiatives, which were further developed in the Five President's report, paved the way for a renovated European integration process, which, if successful, will have no precedent in the history of European integration since the introduction of the euro.

Such reforms, consistent with the idea of 'completing' the EMU (hence, a 'Genuine Economic and Monetary Union'; see Juncker et al., 2015) would not only affect the EMU Member States' governance, but they would also help close the 'credibility' breaches left by a 'Europe in search for its own identity'. Advancing in the European integration process will have an impact on the EU and the single market, with the obvious consequence of affecting the UK as well, and the future of its negotiations (see also Sapir and Wolff, 2016). This may well leave the UK in a difficult position, should negotiations fail to deliver a mutually beneficial deal. Provided that European integration worked in the past, the net benefits of staying out of the EU ex-ante may be different from the same benefits ex-post, particularly in 
the likely scenario the Union will have to 'comprehensively' move forward to safeguard its integrity.

\section{European economic integration}

\subsection{Lessons from the inter-War period}

It is useful to start the analysis by looking at the European sovereign debt crisis through the lenses of the pre-Bretton Woods' period. During the gold standard, the US became a big sink for gold reserves for the rest of the World. Such a strict convertibility of US dollars into gold makes an interesting parallel with the modern EMU, as both systems involve acceptance of monetary and fiscal orthodoxy (Bordo and James, 2013). In the gold standard, the monetary constraint was the convertibility of claims into gold. In the modern EMU, orthodoxy is imposed by the ECB's strict inflation target. By the same token, fiscal orthodoxy implies both regimes to depend on the avoidance of fiscal deficits which would otherwise jeopardize the price stability objective. During the gold standard, most countries had little room to raise money through taxation, causing a concrete constraint on spending (Bordo and James, 2013). In the EMU, the constraint is explicit, with a set-up centered on the idea of "tying one's hands" (Giavazzi and Pagano, 1988), i.e. guarding against government failure by agreeing on strict fiscal rules (e.g., the 1997 Stability and Growth Pact) letting, at the same time, markets find their equilibria (Fuest and Peichl, 2012; see also De Grauwe, 2016a).

During this period many countries, such as Argentina, Brazil, Chile, Italy and Portugal, experienced "sudden stops" of capital inflows (Bordo, 2006), whenever capital markets proved not to be deep enough to borrow in their own currency (i.e. an "original sin"; Eichengreen and Hausmann 1999; Bordo and Meissner, 2007). This situation is reminiscent of the condition of many euro area countries during the sovereign debt crisis since 2010, with the Member States being confronted with market drying out, as the result of a flight-toquality of capital - facilitated by the single currency (see De Grauwe, 2016a) - towards their 'safer' EMU peers.

By the end of 1913, the classical gold standard was at its high but WWI caused many countries to suspend or abandon convertibility, because of this asymmetric adjustment problem (Bordo and Meissner, 2007). The limits of the gold standard can be summarized as a series of impossible trinities (or political trilemmas, Rodrik, 2007; Bordo and Meissner, 
2007), the most interesting one being the political economy trilemma. This principle states that fixed exchange rates, free capital flows, and democratization cannot be observed simultaneously. Here, the lack of democratization is understood as the removal of macroeconomic policy tools from the hands of "democratically accountable governments" (Scharpf, 2011). ${ }^{1}$ This has become (regrettably) relevant for deficit countries within a monetary system. Surplus countries, such as France and the US, at that time, could count on the active monetary policy pursued by their central banks in sterilizing the gold inflows through bonds' sales. This was instrumental in preventing increases of the money stock. Deficit countries, including the UK, on the contrary, faced pressure to deflate, when capital market dried out, in order to generate a medium-term surplus (Eichengreen and Temin, 2010). Given the impossibility to counteract imbalances with the remaining policies, countries were thus forced to 'bring down' their economies; something similar to what Scharpf (2011) calls “bankruptcy-cum-devaluation” in today's terms.

With time, attempts to keep gold parities that were too stringently imposed made several economies to suffer, including the US itself, which collapsed in 1929. The Bretton Woods system (1944) that followed recognized the need to fix the exchange rate, however, under non-total parities. All parities were expressed with respect to the US dollar, with a $\pm 1 \%$ margin. The dollar was itself convertible into gold at $\$ 35 /$ ounce. Although there were a few realignments, the system worked until the 70 s, being to a large degree the basis of the postWWII recovery. The Bretton Woods agreement led to the creation of the International Monetary Fund (IMF), whose role was to provide short-term balance-of-payment assistance using deposits from all members - to countries in deficit. The creation of a liquidity fund after WWII was not accidental as it reflected the inherent asymmetry of the exchange rate parity system: with countries running a surplus having little problem in maintaining the exchange rate at the agreed parity, and countries in deficit eventually running out of reserves, with the obvious route to devaluation.

\subsection{From the Treaty of Rome to the Vote for Brexit}

During the 40s, despite British attitude towards integration remained positive - it is of 1946 W. Churchill's famous speech on the "United States of Europe" - it underlined its scepticism with the major priority of the country in retaining sovereignty. The UK withdrew from the latest stages of negotiations of the first European Community, the European Coal and Steal

\footnotetext{
${ }^{1}$ This is not too dissimilar to the international relations' trilemma: fixed exchange rates, capital flows, national policy independence.
} 
Community (1951) - created to seal a long-term deal between France and Germany - and from the newly-created European Economic Community (EEC), formed with the Treaty of Rome in 1957.

Out of the EEC, the UK decided to join Austria, Denmark, Norway, Portugal, Sweden and Switzerland and create the European Free Trade Agreement (Treaty of Stockholm, 1959). The creation of the EEC, on the one side, and the EFTA, on the other side, gashed Europe in two. With the EFTA, the UK was mainly interested in a different model for integration, based on trade and common agreements. The start of the so-called UK 'relative economic decline' (Figure 1), compared to France and Germany, in particular, saw the UK to later apply to the EEC in 1961, leaving Ireland, Norway and Denmark no alternative than applying as well (Ramiro Troitiño, 2016). The UK's application was rejected in two instances, in 1963 and later in 1967, by the French President C. De Gaulle on the ground of different views on the Common Agricultural Policy. The UK would be able to join the EEC only in 1973 with the change of French presidency. The UK's political demand of joining was by itself driven by two main internal reasons. First of all, there was the necessity to self-legitimate the surrender of the UK's economic centrality in Europe. Secondly, the UK government viewed the continuation of the integration path as a way for own future economic development and political security.

\section{$<$ Insert figure 1 near here>}

The US decision to abandon the gold standard in 1971 (the so-called "Nixon Shock"), brought Bretton-Woods to an end. This stemmed by and large from pressure induced by the US expansionary policies in the late 1960s and early 1970s, coupled with rising unemployment rate and an increasing current account deficit as a part of the financing of the Vietnam War. With a degree of integration of around $78 \%$ and an even higher degree of intra-investment dependence, Europe was too closed and focused on 'internal affairs' to allow for a system of perfectly flexible exchange rates. Moreover, the estimated European trade elasticities with respect to the exchange rate were too high, so that excessive exchange rate fluctuations would have had significantly hurt the trade shares of European countries (Macchiarelli and Sangalli, 2007). In this context, the Werner proposal paved the way for a model of economic and monetary union in Europe for the first time. The 1970s' Plan envisaged a union to be achieved in three evolutionary phases, to be completed by 1980 , including the four freedoms of movement of goods, services, labour and capital, and the total and irreversible convertibility of currencies. At the same time, it recognized the need "for the 
development of [a] political union which in the long run it [the economic and monetary union] will be unable to do without" (Commission of the European Communities, 1970, p.26).

Despite the extraordinary federal reach of the proposal, any possibilities to develop the Plan further were abandoned under the exceptional volatility of exchange rates of those years. The dollar became effectively floated and the best countries could do was a joint float against the US, with the limited fluctuation of each EC currency with respect to each other. This formed the base for the Smithsonian Agreement, created in December 1971, by the 10 largest EC members. By that time, the Community had been enlarged by the entry of Denmark, Ireland, and the UK (Mayes, 2011). This early period is known as the 'snake in the tunnel', as the Smithsonian Agreement permitted not only exchange rate fluctuations of $2.25 \%$ of each currency with respect to the others, but also a $\pm 4.5 \%$ fluctuation limit, representing the 'tunnel' (Mayes, 2011). Market volatility and the supply side shocks of the mid-70s made France, Ireland, Italy and the UK struggle to remain in the snake and exit quite early under the impact of the first oil price crisis. The system continued with Belgium, Luxembourg, Denmark, West Germany, and the Netherlands only, until 1979 (Mayes, 2011).

The mid-70s are critical years for the UK and its relationship with Europe. In 1975, the UK's National front rallied against Europe, with Labour voting to leave the EEC after only 2 years of membership. However, a referendum embraced the European cause and membership to the EEC, all in the same year.

By 1978 the need to achieve exchange rate stability within the Community, and the realization of the risks of asymmetric shocks coming from excessive exchange rate volatility itself (Mundell, 1973), resulted in the then French President V. Giscard d'Estaing and the German Chancellor H. Schmidt putting forward a plan for the creation of a European Monetary System (EMS). This was essentially the result of a political decision. The EMS was initially thought as a way to provide a response to the constraints implied by the macroeconomic impossible trinity. The idea was to make participant countries commit to a system of fixed but adjustable pegs. The key difference from the snake was that instead of being a dollar-based system it reflected purely intra-Community exchange rate "controlled" fluctuations. At the heart of the system were the Exchange Rate Mechanism (ERM) and the European Currency Unit (ECU), the latter being a weighted sum of the nine component currencies. Within the ERM, the same $2.25 \%$ bands were kept, except for Italy, for which a $\pm 6 \%$ band was agreed. The system encouraged coordinated foreign exchange interventions 
and interest rate changes when a country approached the permitted limits. Besides, the EMS conceived issuance of 'private' ECU bonds and related instruments, which large corporates and governments found cheaper and convenient to adopt (Mayes, 2011). J. Callaghan's Britain decided to opt out of the EMS in 1978, until M. Thatcher would open to the possibility of it, with the UK's inclusion more than ten years later, in 1989.

Frequent realignments (11 only in between 1979-1987; see Eichengreen and Wyplosz, 1993) and inflation beginning to take hold turned out soon to alter the symmetric structure of the agreement. The idea was that any countries having troubles keeping within the bands should have started to intervene when the currency had diverged by at least $75 \%$ of the tunnel's edge. When this edge was reached, all such interventions were supposed to be symmetric. In practice, however, the encumbrance of adjustment was primarily placed on depreciating currencies. With West Germany's deflating maneuver having begun in the mid-1970s, the Deutschmark enjoyed higher (than the rest of the EC countries) credibility, soon emerging as the center of the system. Despite the mark's centrality was thought as a way to warrant the system's standing, the EMS gradually started to resemble a 'Deutschmark area', with West Germany leading, and setting its own interest rate for domestic purposes, and the other countries following (Mayes, 2011).

The capital market liberalization of the early 90s, together with the unification of the East with the West, posed a major challenge. In 1992 only, there were 12 realignments. The German reconsolidation, above all, resulted in a large fiscal idiosyncratic shock. High public and private capital inflows to the East (see also Mundell, 1994; Hunt, 2008), as well as the new Deutschemark's attractiveness, created strong appreciation pressure. Initially, the EMS prevented the Deutschemark from appreciating. However, the EMS was only temporarily able to prevent the massive capital inflows (Sinn, 1996). The contingent Bundesbank's decision to raise interest rates to contain pressure on German price levels exacerbated the asymmetry of the shock, especially as Europe was entering a recession (Velis, 1995). For Germany's ERM partners not sharing this need, the appropriate strategy would have been to devalue, but within the ERM this was not straightforward. The system began to fall apart as markets speculated against each of the deficit countries, in turn, forcing them out of the system. As explained by Mundell (1994), "a Europe-wide monetary policy would have cushioned the impact of the German unification shock over the EMS part of the continent. It would have led to more inflation than the Bundesbank wanted, and more deflation than her partners wanted, but a more balanced equilibrium for the fixed exchange rate mechanism". 
Speculation escalated with the pound sterling being first dismissed from the ERM ("Black Wednesday", 16 September 1992), followed by Italy one day later. Spain, Portugal, and Ireland although forced to devalue, continued in the ERM. France, Denmark, and Belgium remained facing severe market pressure. In 1993, under continued speculation, the permitted fluctuation bands were broadened to $\pm 15 \%$, or largely enough to cope with the misalignment and alleviate market stress.

The idea of fixing the exchange rates came back as part of the idea to move to a monetary union under the terms set by the Maastricht Treaty signed in 1992. In 1988, particularly, the Delors' committee set up a framework of economic and monetary integration to be achieved in three stages, echoing the Werner Report, the main idea being that "a single market required a single currency". The project was a very ambitious one, especially because of the turbulent phase (i.e. the concomitant crisis of the EMS; see Eichgreen and Wylopsz, 1994) in which it was presented. With the Report, an eleven-year transition period began before the introduction of the single currency, with national coinages ceasing to legally exist on 1 January 2002. The starting point was participation into the Exchange Rate Mechanism (ERM), followed by the narrowing of exchange rate bands during the second stage. Stage 1 (to be completed by 1990) mostly concentrated on fiscal consolidation, coordination of macroeconomic policy and performance, completion of the single market, and, finally, greater financial integration and coordination of national monetary policies. During phase 2 (up until 1994), a European System of Central Banks (ESCB) was created, and attention was given to harmonizing the monetary policy tools among the Member States. This second stage also saw the birth of the European Monetary Institute (EMI), then European Central Bank. Shifting control of monetary and exchange rate macroeconomic policies from national to the newly born European central bank was a fundamental step of stage 3. During this third phase (ending on 1 January 1999) exchange rates were irrevocably fixed.

The criteria for the run up to stage 3 of the EMU were set in the well-known Maastricht criteria (Treaty on the European Union, Maastricht Council, December 1991). While achieving an immediate monetary integration would have probably been desirable in a longrun perspective (Eichgreen and Wylopsz, 1994), it seemed unrealizable from both a political and economic perspective. The Maastricht Treaty was successful in correctly signaling a "convergence of preferences" among member states, by setting up a clear timeline for integration. That is why Maastricht has to be primarily understood as a political process, 
which flourished particularly thanks to the "bargain" between Germany and France (Baun, 1996).

The collapse of the EMS in 1992 was giving clear evidence that monetary convergence was any longer sufficient neither to guarantee the credibility of fixed exchange rates nor to prevent systematic imbalances to occur. This is why the Maastricht criteria created the occasion to outwit the foregoing stability condition in inflation rates, requiring additional convergence in interest rates and exchange rates (Macchiarelli and Sangalli, 2007), as well as fiscal policies. The latter particularly, reflected the idea of acquiescence to clear fiscal targets, i.e. fiscal orthodoxy (see Bordo and James, 2013) which - together with an explicit provision to discourage governments to resort to price rises for debt financing (i.e. 'no monetary financing' - Art. 123 TFEU) - was seen as a way to reduce the risk of high inflation (see Giavazzi and Pagano, 1988; Chari et al., 2015). In this respect, the Maastricht criteria - albeit controversial in today's terms (De Grauwe, 2016a) - were numbers reflecting political realities at that time, and not just discrete targets (Klein, 1998). ${ }^{2}$

<Insert table 1 near here>

Already in 1988, M. Thatcher announced Britain's intention not to join the European economic and monetary integration plan. That was followed by severe political turmoil in the UK, with the Secretary of State for Trade and Industry, N. Ridley, being forced to resign in July 1990 following a controversial interview, and the UK's deputy Prime Minister, G. Howe, resigning in November of the same year because of his disagreement with Thatcher's opposing policy towards the single European currency. Thatcher will resign 3 weeks later.

With the first 11 countries signing up to the euro, on stage 3 of the EMU, Britain stayed out. In the negotiations leading up to Maastricht, the UK was granted an opt-out clause. Technically it was not eligible because of 2-year ERM criterion; in practice, it would have been almost certainly granted admission based on the standard macroeconomic convergence indicators (see also Ramiro Troitiño, 2016). Looking at the period averages reported in Table 1, in the decade elapsing in between stage 1 and 3 of the EMU, the UK performed quite well with respect to the Maastricht criteria. The pattern of short-term interest rates at 1-month maturity (Figure 2) after the euro suggests - however - a monetary policy stance which is specific to the country (see also Holden, 2009). Chiefly, with the decision to stay out, the United Kingdom retained sovereignty and the right to conduct autonomous monetary and

\footnotetext{
${ }^{2}$ For a critical discussion, see also De Grauwe (1994).
} 
exchange rate policy. This was different for the euro area, where monetary policy decisions were indeed delegated to the Governing Council of the ECB for all euro area countries; a stance now identified with the much-discussed term 'one-size-fits-all' (see Peersman and Smets, 1999; Nechio, 2011). ${ }^{3}$

\section{<Insert table 2 near here>}

During the first years after the introduction of the euro, the British pound appreciated against the new currency, to some extent following the strong US dollar (Figure 2). For the pound, sizeable fluctuations have persisted through the whole sample period as the pound has appreciated even more before the vote of June 2016, largely driven by "safe-haven" effects. In the debate about monetary union membership, one concern for the UK was to maintain the credibility of monetary and exchange rate policy. The numbers in Table and Figure 1 suggest that 'borrowing credibility' was indeed never a concern for the UK, which fared relatively well in keeping inflation in check, with the possible exception of the immediate post-crisis period.

\section{$<$ Insert figure 2 near here $>$}

In 1997, the UK committed itself to joining in principle the single currency, but with a number of caveats (the so-called G. Brown's Five Tests), the main one being that EMU membership should have been achieved in the national interests. In 2003, a review by the UK Treasury concluded that the investment and financial services tests were met, but the convergence and flexibility tests were not. Thus, the Treasury's assessment, i.e. that "a clear and unambiguous case for UK membership of EMU has not at the present time been made and a decision to join now would not be in the national economic interest", 4 reduced membership to a technical matter, showing once again British relation to the integration process as a very pragmatic one, with the country expecting an immediate, or anyway shortterm, payback for its contribution. ${ }^{5}$ This is something dating back already to 1984 with Thatcher's infamous "I want my money back" struggle to reduce Britain's EEC budget participation. It is in this environment that the then Prime Minister T. Blair committed to a referendum on Europe's Constitutional Treaty in 2004, which happened to never occur. Ten

\footnotetext{
${ }^{3}$ Nowadays, as a member of the EU (still), the UK sits the General Council of the European System of Central Banks (ESCB), comprising the President and Vice-President of the ECB, plus the governors of the national central banks of the 28 EU States.

${ }^{4}$ Emphasis added.

${ }^{5}$ Clearly, the idea of membership being in the "national interests" also relies on the national history linked to the traditional role of the pound and political reputation (see De Grauwe, 2016; Holden, 2009).
} 
years later, on Jan 2013, Prime Minister D. Cameron promised a second time to give the British people the "simple choice" by the end of 2017 between staying in the EU under the UK's renegotiated terms, or leaving. The European Union Referendum Bill became law in May 2015, resulting in the June 2016 historic vote to leave. ${ }^{6}$

\section{Understanding integration}

By looking at the history of previous monetary systems in Europe, there is something to learn about the state of health of the monetary union today. Undoubtedly, the relaxation of fluctuation limits during the EMS has generally provided countries with the needed flexibility to adjust to shocks. However, this has to do more with the EMS set-up rather than fixing of the exchange rate itself.

During the 70s inflation was the major spectrum to fight, especially after the supply side shocks of those years. In both the EMS and the EMU, the asymmetry of the adjustment problem forced a strategy of disinflation on deficit countries - appealingly exploiting the lessons from the German Bundesbank - which soon proved not sustainable. This strategy has historically exposed the system's difficulty in managing idiosyncratic shocks, maintaining, at the same time, credibility. Particularly, there are two main channels through which credibility problems may arise both in a system of fixed exchange rates without a currency (Macchiarelli and Sangalli, 2007) - like the EMS - and in the system of a currency without a nation - like the EMU. In both systems, these can be identified as (see also Weber, 1991; Salvatore, 1997; De Grauwe and Ji, 2015):

i. Adjustment costs;

ii. Liquidity or coordination costs.

In the history of monetary integration, countries losing the ability to use the exchange rate suffered from costly adjustments ex post mainly in terms of unemployment. As far as the EMS is concerned, De Grauwe (1994) shows how both the average unemployment rate and the inflation differential with respect to the reference currency had a significant impact on the credibility of the system. It is thus clear that the convergence of inflation rates pursued during the 1980s, although necessary for the well-functioning of the system, was not sufficient to prevent speculative crises, particularly in the lack of structural reforms. The liquidity problem

\footnotetext{
${ }^{6}$ Technically, under the provisions set by the 2009 Lisbon Treaty (Art. 50).
} 
for the EMS was, on the contrary, a typical $n-1$ problem in which choosing the appropriate monetary policy prevailing through the system resulted in a coordination failure (De Grauwe, 1994)- i.e. whenever the member countries felt that the monetary stance undertaken by the leading currency may not have been representative of the system as a whole. The EMS suffered from a lack of credibility because it was set-up on a union in which national currencies were to be maintained with 'irrevocably' fixed exchange rates. This was just inefficient in dealing with asymmetric shocks (De Grauwe, 1994; De Grauwe and Ji, 2015).

As for the EMU, the aforementioned adjustment problems can be understood as a moralhazard problem. The very disappearance of the exchange rate led to protectionism, access to larger than domestic capital markets (the so-called "common pool" problem; see, inter alia, Kontopoulos and Perotti , 1999; Wyplosz and Kostrup, 2010), and a higher capacity to borrow, overall weakening incentives for structural reforms (see Calmfors, 2001). Such weak leverage for adjustment exacerbated divergence issues in some countries, resulting into higher than necessary adjustments' costs later on (see De Grauwe, 2016a). That is to say that the creation of a currency union in Europe weakened the incentive for a market-based flexibility that could have offset (or at least limited) the loss of exchange rate as an adjustment tool (see also Bean, 1998; De Grauwe, 2016a).

The liquidity problem in today's terms is slightly different than the one countries were confronted with during the EMS. This problem has to do instead with the "fragility" of a system centered on $n$ Treasuries and 1 central bank. Hence, the problem of a currency with 'too many countries' (see also De Grauwe, 2016a; De Grauwe and Ji, 2015). In this system, not only countries will issue debt in a currency they have no control of (a situation reminiscent of the gold standard's "original sin", as we recalled), but also the presence of a "lender of last resort" for sovereigns is not granted. As explained by De Grauwe (2016a), differently from a stand-alone country such as the UK, the Treasury of any EMU member states not only will not benefit from the exchange rate tool in cushioning shocks - thus preventing capital flights-to-safety towards other EMU countries - but also they will not have the unconditional backup of their national central bank. Simply because in the EMU there is no effectively functioning national central bank, with the exception of the ECB. The ECB could certainly intervene and act as a "lender of last resort", as it did exceptionally (see Gerba and Macchiarelli, 2016). However, the European Bank will have the major constraints deriving from the complexity of the governance framework of the monetary union (Gerba and Macchiarelli, 2016): again 1 central bank and $n$ Treasuries. In the jargon of game theory, 
the problem with this set-up is that the Member States' fiscal authorities will be better off if the ECB intervenes, obviating the need for fiscal intervention. Likewise, the ECB will be better off if the governments agree to use their fiscal stimulus, thus alleviating the pressure on the ECB itself (see Onorante, 2007; Alcidi and Giovannini, 2013). Once again, this gives rise to coordination failures.

\subsection{Theory behind economic integration}

From a theoretical standpoint, the "economics" of European integration can be understood under two broad headings. The first is the optimal control approach or the political economy of strict fiscal rules (see Fuest and Peichl, 2012; De Grauwe, 2016a), discussed earlier. This approach tends to identify in the moral hazard implicit in pooling the exchange rate and monetary policy competencies as the main problem within a currency union. A second popular set of tools is the Optimum Currency Area (OCA) first developed in the 1960s (Mundell, 1961; McKinnon, 1963), and centered on the idea of trade openness, the flexibility of (labor and product) markets, and business cycle's symmetry. The UK's attitude towards the EU has historically put much emphasis on the former.

The main research question driving the scholarship on OCA has to do with the costs and benefits of sharing a currency (Alesina and Barro 2002). The main cost is the loss of monetary policy and exchange rate autonomy, the latter being particularly relevant in the presence of asymmetric shocks. Benefits are mostly in terms of reduction of transaction costs and exchange rate uncertainty, and of increasing price transparency, trade, and competition. Other recent work calls the attention to the role of credibility shocks. If there are varying degrees of commitment, countries with dissimilar credibility shocks, which exacerbate time inconsistency, may find profitable to join a currency union (Chari et al., 2015).

The existence of idiosyncratic shocks alone is not sufficient to establish the case for retaining separate currencies. Nominal exchange rate realignments are only helpful in facilitating adjustment when nominal wages and/or prices are not flexible. In other words, the pattern of asymmetric shocks across countries depends on the degree of nominal inertia. ${ }^{7}$ De Grauwe and Mongelli (2005) have studied the interactions between symmetry, flexibility, and integration in an OCA framework. For both pairs 'symmetry vs. flexibility' and 'symmetry

\footnotetext{
${ }^{7}$ In more general terms, however, also fiscal adjustments at the euro area level (on top of flexibility) could replace the lack of monetary policy autonomy when countries face divergent patterns (i.e. like in the US; see Mundell, 1973).
} 
vs. integration' the relation is downward sloping (Figure 3). ${ }^{8}$ Focusing on the degree of economic integration and symmetry and how it evolves over time, there are different views on such evolution (as illustrated by arrows around the EU and Euro circles in the Figure; see also Krugman, 1993). In Figure 3, the downward sloping OCA-line shows the minimum combinations of symmetry and openness that countries must have in order for a monetary union to provide positive net benefits.

\section{<Insert figure 3 near here>}

A similar relationship exists between symmetry and flexibility. In particular, countries or regions located below the OCA line do not have enough flexibility given the level of symmetry they face. Countries to the right of the OCA line have a lot of flexibility given the level of symmetry they face. Ultimately, the empirical evidence about how many countries in the $\mathrm{E}(\mathrm{M}) \mathrm{U}$ form an OCA is not clear-cut. Particularly, for the UK the empirical evidence based on these three factors is rather mixed (see De Grauwe, 2016a; Campos, Coricelli, and Moretti, 2014; Campos and Macchiarelli, 2016b; Pesaran, Smith and Smith, 2007; Holden, 2009).

\subsubsection{Openness}

While one would expect a monetary union to have a positive effect on trade, given a reduction in transaction costs and exchange rate risk, as well as higher price transparency, as discussed, the size of the estimated effect of currency unions on trade varies. Seminal work by Frankel and Rose (1998) suggested possible endogeneity of currency unions: i.e. where more openness did not have to be met ex-ante but rather will ex-post. However, recent econometric evidence reports "no substantive reliable and robust effect" of currency unions on trade, overall challenging this wisdom (Glick and Rose, 2016). Yet, the degree of openness is, vice versa, likely to increase the benefits. The evidence suggests there are large differences in the openness of EU countries with the rest of the Union. For the UK, trade of goods between the UK and the rest of the EU is typically low (De Grauwe, 2016a), whereas much of the trade share is accounted by financial services (Source: Office for National Statistics).

\subsubsection{Flexibility}

\footnotetext{
${ }^{8}$ Another important recent strand highlights situations when OCA criteria are interdependent and focus on interactions between openness and mobility (Farhi and Werning, 2015).
} 
The lack of independent monetary policy within a monetary union raises the call for labor market flexibility. In particular, in Mundell's (1961) and McKinnon's (1963) original framework the degree of labor market flexibility matters for determining whether a monetary union is attractive to countries (De Grauwe, 2016a). When it comes to flexibility, one can distinguish between (i) the pace at which people transition in and out of work, or across sectors, and (ii) wage flexibility. Looking at standard indicators for flexibility, such as individual protection, the use of temporary work, and collective dismissal, the UK typically scores low on the protection of individuals, along with other Anglo-Saxon economies, standing in contrast to other continental European countries such as in Germany, Italy, and France where protection is significantly higher. The same contrast is true also for temporary work, with very a strict regulation in Spain, France, and Italy, differently from Anglo-Saxon economies (2013 OECD's data from the Chartered Institute of Personnel and Development). As underlined by Holden (2009), despite the UK labor market being among the most flexible in Europe, the 1993 Treasury Assessment based on the 5 Tests highlighted skepticism as to whether flexibility would have been sufficient to cope with a monetary union (Holden, 2009). The second key aspect of the labor market flexibility is wage setting. The UK has started an important process of decentralization of wage setting since the 70s (Source: Golden and Wallerstein's database, 2006) suggesting a greater degree of moderation (see Calmfors and Driffill, 1988; Driffill, 2006), hence normally being better positioned in facing supply side shock within a monetary union (see also De Grauwe, 2016a).

\subsubsection{Symmetry}

The efforts to create a European monetary union have sparked increased interest in measuring the synchronization of the business cycles since the beginning of the 1990s. A high level of convergence among the national business cycles, which is the absence of sharp asymmetrical shocks between one country and the euro area, is an important criterion for an OCA. The extent of synchronization between the euro area and the UK studied here can be determined by the correlation of the cyclical components (HP-filtered) in their industrial production (Figure 4; see also Artis, 2003). The cyclical component is calculated as the difference between industrial production growth and an estimate of the trend. Since the euro introduction, the UK's volatility has been considerably lower (Table 3), with this stability being typically attributed to strong domestic demand, with private and public sector consumption and capital investment on new construction contributing to stabilization (Moser et al., 2004). Table 3 also shows that, since the start of EMU, the business cycle of the UK 
has been correlated considerably with that of the euro area. What is striking is the low level of the correlation for the United Kingdom and the euro area at the beginning of the series, before the EMU (Massman and Mitchell, 2002; Campos and Macchiarelli, 2016a), something possibly attributed also to the UK sterling dismissal from the EMS in 1992. These fluctuations in the real activity-gap have become smaller over time (see Campos and Macchiarelli, 2016a), with correlation being stronger in the second half of the sample. Several studies show that the convergence between the Eurozone and the UK has increased since the EMU (e.g. Angeloni and Dedola, 1999; Campos, Coricelli, and Moretti, 2014; Canova et al. 2005; European Commission, 2008; Massman and Mitchell, 2002). In spite of more synchronization, there are still sizeable differences, particularly in the extent monetary policy (captured by short-term interest rates) has been conducted. Assuming a lower interest rate in the UK during the mid-2000, mimicking the ECB's path would have clearly stimulated the late 2000s bubble in property prices further, presumably making the 2008-09 bust sharper (Holden, 2009). However, all such conjectures are purely speculative, as well they present an obvious endogeneity problem. By the design of the EMU, the ECB is constrained to a "one-size-fits-all" monetary policy - the latter being likely to increase the costs of joining the EMU the most de-synchronized are the Member States' cycles. Nonetheless, should the UK have joined, the optimal monetary policy response of the ECB would have possibly been different, reflecting the size and the importance of the UK economy as well (see also Nechio, 2011; Peersman and Smets, 1999).

$<$ Insert figure 4 near here>

<Insert table 3 near here>

\subsection{The EMU convergence criteria: a second look}

Although it is unclear what the prospects for the UK will be outside of the EU, a continuation of the process of European integration, in theory, would be weighed based on the Maastricht convergence criteria. The problem with these criteria has always been political. The Maastricht Treaty was, in fact, paying attention to the idea that, in order to join the new arrangement, countries had to converge sufficiently in their monetary and fiscal policies. Already at the time of their adoption, the unstable conjecture inherited from the EMS crash have probably been "the driving factor in widening the perception that the required criteria were almost paradoxical” (Macchiarelli and Sangalli, 2007; see also De Grauwe, 2016a). The political paradox was, inter alia, accentuated by the evidence that many countries were 
finding it difficult to fulfil these criteria using policies of fiscal stabilization which were accompanied by economic stagnation, thus keeping actual budget deficits high (as a \% of GDP), in spite of any significant attempts to cut public spending (Macchiarelli and Sangalli, 2007). Once again, political support among member states remained the strongest in pursuing these goals, above and beyond economic reasons. That is what historically lacked in the UK.

Some (e.g., Baldin \& Wyplosz, 2006) have argued that the necessity of the stringent convergence criteria, conceptualized through the adoption of the Maastricht Treaty, was a main attempt to compensate for the fact that Europe was indeed not an OCA. In this respect, the main concern for any enlargements of the monetary union to any other country, including the UK, would be again represented by the costs of adjustment in order to deal with asymmetric shocks. In the absence of sufficient labor market flexibility and/or of fiscal transfers at the euro-area level, many countries would suffer from severe adjustment problems. As the crisis made very clear, the lack of such adjustment mechanisms, in the presence of asymmetries, has made adjustment costs ex post very high in order for the integrity of the monetary union to be preserved (see Scharpf, 2011; De la Dehesa, 2012).

Already since before the start of the EMU, this conception of asymmetries has spurred an alternative approach to European integration: the possibility of a two-tier or 'multi-speed Europe'. Not least, during the recent (at the time of writing) EU6 Summit in Brussels, the limitations of a treaty commitment to pursue the "ever closer union" of the peoples of Europe were reaffirmed as a part of a package to facilitate Cameron's campaign before the referendum. While acknowledging that the Union "allows for different paths of integration", however, European negotiators (French and Belgium in particular) were against the idea of a 'pic-n-mix' Europe by adding a clear re-statement of the principle that all countries - unless they have an explicit exemption like Denmark (or Britain, before the referendum) - must ultimately join the single currency.

\section{$<$ Insert figure 5 near here>}

From an economic viewpoint, it is true that smaller groups of selected countries may be better candidates in forming an OCA, given the homogeneity that characterizes them (see also De Grauwe, 2016a). Looking at the early evidence on the degree of synchronization of shocks across countries before the EMU $(1963$ - 88), it seems that, with respect to the supply side, one can identify a "core" region-Germany, France, Denmark and Benelux, where the shocks are highly correlated, as well as a "periphery" region where the correlation with the anchor 
region is much lower (Bayoumi and Eichengreen, 1993). With respect to demand shocks, there is more of a difference: the correlation with Germany is much lower, even for the other countries of the European core. The EMU may have eliminated independent national monetary policies as a source of idiosyncratic demand shocks, but national fiscal policies remained independent so the cross-country correlation in movements in demand may well persist (see also ECB, 2011a). Using Bayoumi and Eichengreen (1993) criterion on the supply-side core-periphery divide, Campos and Macchiarelli (2016b) show that the UK has moved from the periphery $(1963-88)$ to core $(1989$ - 2015) (Figure 5). The results for the UK are admittedly not strong. Said that, however, a new, smaller, periphery has emerged (Spain, Portugal, Ireland and Greece). Thus, the EMU has actually weakened the coreperiphery pattern, resulting into countries being more integrated over time.

To conclude, while the hypothesis of a 'multi-tier' Europe cannot be dismissed based on the little evidence available, there is a second (and opposite) alternative to a 'multi-speed' line of work: a process of reform and - possibly - deepening. This is the spirit of the 5 Presidents Report, which we will cover in the next section. 


\section{Towards a GEMU}

The 5 President Report is a far-reaching initiative for a "deeper and fairer" Union, focusing on four key policy areas (Junker et al., 2015; see also Begg, 2014): an integrated financial framework to ensure macro and micro financial stability and supervision at the euro area level; an integrated fiscal framework with the dual goal of delivering discipline and developing new common fiscal policy instruments; an integrated economic policy framework to ensure macroeconomic policy coordination, fairness and competitiveness; and finally, enhancement of democratic legitimation (see also Scharpf, 2011).

The key question the Report seeks to answer is: where did the EMU fail and how can it be fixed? (see Pisani-Ferri, 2012; 2013; De la Dehesa, 2012; De Grauwe, 2016a; Scharpf, 2011). The Report consists of "short term", "medium term" and "long term" reforms; i.e. as clearly a fiscal or a political union will take longer, given the transfer of sovereignty they involve, than (the existing) bank supervision (see Macchiarelli, 2016 ), or coordination of macroeconomic and fiscal policies, which are short to medium term measures. The timeline of the 5 President Report, particularly, reads as follows:

A first phase (between now and early 2017) of "deepening by doing", building on the existing EMU framework and instruments, including legal provisions, with a view to boost competitiveness and structural convergence, achieving budgetary discipline at national and the euro area level, completing financial integration (i.e. a capital market Union, federal Resolution, and European deposit insurance are on the way), and increasing democratic accountability. A second phase of "completing EMU", including medium to long-term reforms, also of legal nature, with a set of commonly agreed benchmarks for convergence. A third phase (to be completed by 2025) of furthering integration - this phase will not exclude other EU countries from joining.

\subsection{Is "completing" the EMU compatible with dropping the "ever closer union" clause?}

The key question, in the light of the state of the EU-UK negotiations before June 2016, is whether "completion" of the Union would be compatible with the dropping of the clause of "ever closeness". Let me start by saying that the answer to the above question should be negative. This does not mean intermediate solutions cannot be found in seeking an agreement 
with the UK. Particularly, there are at least two arguments for the answer above, both falling under the remit of political economy.

The first motivation is political.

Many parties have voiced concerns that a British-exit could be the beginning of the end for Europe, or - not least - lead to a stall in integration. In their view, the UK could be followed by other countries, creating a legal precedent in the European integration path, within the remit of Lisbon's Art. 50. Let us not forget, however, that the UK's vote to leave was the peak of an iceberg, preceded by a period during which Europe has been gripped in waves of Euro-scepticism (see also Mongelli, 2013). This trend is strictly linked to the notion of Weber's credibility (Weber, 1991); the latter always having been considered a key issue in Europe's identity. Low credibility has been cyclical in the history of European integration, in some sense accompanying the recessive phases of the economic cycles (Macchiarelli and Sangalli, 2007) whenever those translated into crises challenging the prevailing paradigm or exposing the system's inherent fragilities. This continuous search for credibility has worked as an accelerator to the process of integration, leaving in most cases European countries no chances but joining in (Macchiarelli and Sangalli, 2007). The underlying logic to the convergence criteria has to be evaluated in the light of the will of conditioning expectations concerning the future path of the European economic and monetary union (i.e. a "convergence of preferences"). The question of a currency without a nation, together with that of 'betrayed expectations' in terms of post-euro introduction growth, is nowadays the most compelling elements holding the EMU's credibility down (Macchiarelli and Sangalli, 2007). Particularly, the realization that the positive cycle after the period of very slow growth characterizing the mid-2000s was by and large 'bubbly', and coming at the exposes of a growing north-south divide (see De la Dehesa, 2012), raised many questions concerning the long-term viability of the European project.

Agreeing to the idea of transition to a GEMU, albeit sounding unprecedented, could indeed ensure that needed convergence in a political sense, in a period in which the credibility of the Union is at stake and its democratic base drifting away. The UK never really bought into the European project with a view of being a part of an "ever closer" union, but rather to balance power within Europe. This explains why British attitude has frequently been based on dismissing or openly rejecting further steps of integration. 
There is little clarity about what new relationship the UK and the EU will seek within each other. However, concerns about preserving and defending European integration should be the point starting from which the EU will need to negotiate a new agreement with the UK (see Oliver 2016). ${ }^{9}$ That is to say that it is now crucial for Europe to provide an alternative model of integration for countries like Sweden, Denmark Poland, or other 'pre-ins', avoiding unleashing centrifugal forces which could unravel the Union itself. At the same time, further integration would prevent a 'controlled' disintegration path through a multi-speed approach. Providing this alternative model is thus not imaginable without committing to transitioning to a GEMU.

The second motivation is economic.

Let us start with the conceptualization of the EMU's sovereign debt crisis as a vicious circle, the so-called 'doom loop'. The sovereign debt crisis that started in 2010 exposed the very "fragility" of the EMU architecture (De Grauwe, 2016a), highlighting the danger of an unfinished set-up at the core of the "wrecking spiral" (Macchiarelli, 2016) between public and private debt. Following on from our previous discussion, the 'doom loop' took place when one or more conditions were met:

Liquidity costs

a) Lack of fiscal discipline

b) Excess of private debt

Adjustment costs

c) Lack of structural reforms

The accumulation of imbalances that characterized the pre-2010 - facilitated by the ECB's 'one-size-fits-all' policy, and loose financial market regulation (see Pisani-Ferri, 2012; 2013; De la Dehesa, 2012; De Grauwe, 2016a) - resulted into countries being unable to stall the crisis, needing a coordinated support at the European level. For banks, for instance, last-resort guarantees from governments to their own financial institutions (see also Gros and Schoenmaker, 2014) resulted in higher public debt and generally large costs to taxpayers (see Macchiarelli, 2016). In several cases, e.g. Spain or Ireland, this resulted in a self-reinforcing amplification effect relating to the classical problem of (ir)rational runs in which the market

\footnotetext{
${ }^{9}$ A British exit could hit EU-NATO relations at a time when the US government is pushing for enhanced geopolitical relations with the EU through the Transatlantic Trade and Investment Partnership (see Hamilton 2014).
} 
can push an economy into a "bad" equilibrium (see also De Grauwe and Ji, 2013; De Grauwe, 2016a). This amplification within the EMU had to do (Macchiarelli, 2016), at first, with a collapse of confidence in certain markets and financial institutions at the same time, and the broader fragility of systems, because of increased risk or asymmetry of information (see also IMF, 2013). Secondly, the interaction between bond prices (via banks' balance sheets) and borrowing constraints, where - to make things easy - the fire-sale of government bonds and rising of risk premia had a negative effect on the banks' net worth, with an ensuing liquidity dry-out and freezing of lending to the real economy. Figure 6 summarizes this discussion.

As Macchiarelli (2016) shows, should the 5 President Report not be adopted, there would be relatively little change compared with the position reached as a result of the governance changes already introduced since 2010 (see ECB, 2011a). This could result into the GEMU not making it through to stage 2, resulting into the aforementioned 'doom-loop' not being completely broken (see also Begg, 2016). A 'Comprehensive GEMU' (Begg et al., 2104), on the contrary, would include an extensive and progressive adoption of the additional transfers of power to the European level, resulting not only in an extraordinary development in a federal sense, in the long term, but also in the loop being finally broken (Figure 6).

As a matter of fact, the Union has very little options outside transitioning to a GEMU. Otherwise the EMU would be characterized by yet another "impossible trinity" (Pisani-Ferri, 2012) - absence of co-responsibility over public debt, strict 'non-monetary financing' rule (Art. 123 TFEU) and the combination of free capital movements and national responsibility for supervising and, if needed, rescuing banking systems - which the 5 President Report is committed to break. This will chiefly be through the introduction of a fiscal and a banking union. A political union will be then required not to violate the archetype of "no taxation without representation".

\section{$<$ Insert figure 6 near here>}

It is worth noting that these reforms, however, implemented, would not only affect the EMU Member States' macroeconomic, financial, fiscal, and political governance, but they would have an impact on the EU and the single market, with the obvious consequence of affecting the UK as well, and the future of its negotiations (see also Sapir and Wolff, 2016). In the best case scenario, advancing in the European integration process may result in some of the 'euroouts' to make use of their option to opt-in going ahead. This may leave the UK in a difficult 
position, should EU negotiations fail to deliver a solution convenable for both. Provided that European integration worked in the past, the net benefits of staying out of the EU ex-ante may be different from the same benefits ex-post, particularly in the likely scenario the Union will have to 'comprehensively' move forward for its own survival.

\section{Looking forward}

Seeking immediate benefits from membership to the European project has its limitations. Historically, even in continental Europe, more integration in a federal sense was limited to the extent that the interests of the EU itself (or, joint EU utility) did not necessarily match the sum of the utility of individual Member States (or, aggregate utility). This has had significant implications for the process of EU integration as a whole (Begg et al., 2014). The crisis is gradually changing this predicament, as the skewed design of the system (a strong monetary leg and a weak economic leg, or the ECB's “institutional loneliness" as the former ECB's Governing Council member, T. Padoa-Schioppa, eloquently put it) ${ }^{10}$ resulted in larger costs for the EU if taken together. ${ }^{11}$

Most views are that the outcome of the referendum - a reflection of "British exceptionalism" - will cost heavily economically, mainly to Britain. The EU would feel some knock-on costs as well, with the EU reduced weight on the international political grounds (Butler et al. 2016). Brexit will certainly change both the internal and external equilibrium, with some EU non-euro area member states such as Poland, Denmark, and Sweden, but also other 'pre-ins', feeling they will lose grip in shaping euro zone policies (Oliver, 2016), especially against an enhanced role of Germany and the other euro area member states. This may trigger further skepticism, should the EMU fail to provide an attractive alternative model for integration. Deeper integration should carry on to the point of making euro-outs use their option to opt-in; something which is indeed not excluded by phase 3 of the Presidents Report. Any suboptimal solutions may be costly for the future of Europe's integration path.

There is no definitive study on the consequences of the impact of EU membership on the UK (see Fig 7). Hence, in terms of the UK withdrawal, much will depend on how successful the

\footnotetext{
${ }^{10}$ See Padoa-Schioppa (1999).

${ }^{11}$ It is enough to think the used state aid measures in the form or recapitalization and asset relief measures to European banks between Oct 2008 and Dec 2012 amounted to 591.9 billion or $4.6 \%$ of EU 2012 GDP, with the highest share belonging (in the order) to Ireland, the UK, and Germany (Source: European Commission State Aid Scoreboard, 2013). Including approved aids and guarantees, this figure jumps to over $12 \%$ of the EU GDP for the period 2008-12 only.
} 
current Prime Minister, T. May, will be in framing the outcome of the renegotiation. In this respect, there is evidence suggesting that May's job will not be the easiest one. Indeed, as Goodwin and Milazzo (2015) points out, when voters were last asked about the future of Britain's relationship with the EU (in 2014), using a question moving away from the usual binary 'remain-or-leave' scenario, a majority (40\%) were willing to remain within a reformed EU with reduced powers. ${ }^{12}$ This is all not surprising, but it suggests PM May may have a hard time to renegotiate an agreement keeping the UK strong, with the right of entry to many of the EU benefits. Something the EU certainly cannot afford.

While it is difficult to quantify now whether or not the UK would flourish outside the EU, it is safe to play an exercise in reverse. Withdrawal is likely to have an impact, particularly on some sectors, like farming (currently receiving subsidiaries through the CAP), investment, education, and finance. In terms of budget, for instance, while the UK pays more into the EU budget than it receives from it $(-0.46 \%)$, the net balance is not different from that of the Nordic EU non-euro area countries such as Denmark (-0.49\%) and Sweden $(-0.51 \%)$. Other countries having a negative balance are: Luxemburg and Italy (about 0.20\%), Finland ( $0.30 \%)$, Austria, France, Belgium ( 0.40\%), the Netherlands $(-0.45 \%)$ and Germany ($0.49 \%$ ) (Source: European Commission's "Financial Programming and Budget: UK"). ${ }^{13}$ Although the UK is a net contributor to the EU, certain regions receive significant support from the budget through the European Regional Development Fund and the European Social Fund. These receipts from the EU budget, for the latest year for which data behind the calculations are available, show that Wales - with a large agricultural sector - received as much as $£ 163$ per head. England received just $£ 52$ (Source: HM Consolidated statement on the use of EH fund in the UK). Such a variance in public sector receipts means that some parts of the UK (Wales and Northern Ireland) are net recipients from the EU budget while others (England and, to a lesser extent, Scotland) are net contributors. However, the net balance does not reflect the many benefits of EU membership, many of which are difficult to quantify, such as stability, security, freedom of working, living, studying and traveling within the EU. The UK government estimates that the single market brings in between GBP 31 billion and GBP 92 billion a year into the UK economy, equal to a contribution 5 to 15 times larger than the net UK contribution to the EU budget (Source: European Commission). The

\footnotetext{
${ }^{12}$ This was followed by leave (25\%) and people supporting a scenario with the EU staying the same (18\%). The popularity of an enhanced EU or even its evolution to a single government including the UK was the lowest (Source: British Social Attitudes Survey, 1993-2014).

13 European Commission's website "financial Programming and Budget: UK" http://ec.europa.eu/budget/mycountry/UK/index_en.cfm
} 
UK is also one of the top recipients of EU research funding. The UK Office of National Statistics (ONS) reports that the UK's contribution to EU research and development of $€ 5.4$ billion over the period 2007-2013. The UK received $€ 8.8$ billion in direct EU funding for research, development and innovation activities during the same period (see also the Royal Society, 2016).

Finally, on the issue of finance, the current approach to a European banking union (see Macchiarelli, 2016) lets foresee that the problem of funding of financial institutions will be accentuated with the UK withdrawal, having a strong impact on the extent cross-border externalities of bank failures across the EU will be addressed, particularly when they will involve guarantees to or resolution of banks which are systemic in both the euro area and the UK. While, going ahead, some of the other 'outs' may make use of their option to buy-in (see also Gros and Schoenmaker, 2014), provided that European resolution and deposit insurance schemes will be available, the UK's move to stay out will leave the UK and the EU in unchartered waters, given the large presence of important European banks in London. This may change going ahead.

\section{$<$ Insert figure 7 near here>}

\section{Conclusion}

To conclude, despite the risks that a multi-layer crisis poses to the very existence of the EU, the assumption that this could lead to less integration does not seem obvious by looking at the history of European economic and monetary integration. Being today some of the most crucial elements of integration at risk - the single market and people's ability to move freely, and the single currency itself - Europe should use awareness of its existing limits to initiate a process of reform and, hopefully, deepening. This is the spirit of the 5 Presidents Report. The justification of such a process of "completing" the EMU can be rationalized both under economic and political terms, being the only root to a renewed European credibility. It remains to be asked - now that the British claims as a part of the package to stay in the EU have been discarded by the exit vote - whether the space for European integration may even be larger (see also De Grauwe, 2016b). This will all depend on how "low profile" the UK will accept to be in the future of Europe. 


\section{Figures and Tables}

Figure 1 - GDP evolution in Germany, France, Italy and the UK's relative decline

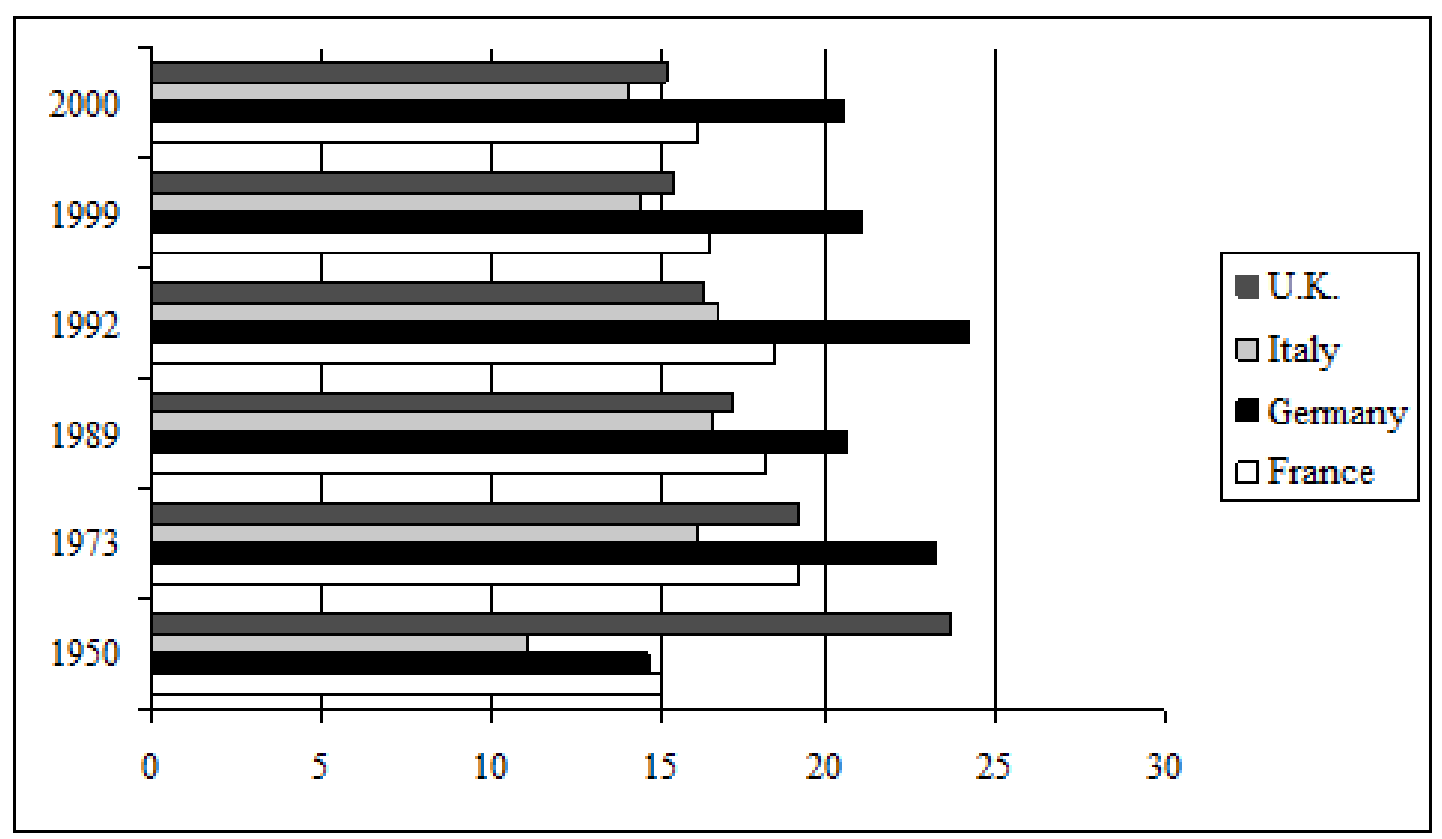

Source: Data from Valli (2002). Note: Data are in PPP for all countries but Germany. German data refer to the Federal Republic between 1950 and 1989. 
Table 1 - The orthodoxy in the Maastricht criteria

"Monetary orthodoxy"

Inflation rate not exceeding 1,5\% of the mean of EC countries with lower inflation.

The interest rate on long-term Government Securities not greater than $2 \%$ with respect

to the mean of the three least inflation countries.

Exchange rate within the ERM fluctuations margins for at least 2 years.

"Fiscal orthodoxy"

Gross public debt not exceeding $60 \%$ of GDP, or converging at a "satisfactory pace".

Public deficit not exceeding 3\% of GDP. 
Table 2 - Macroeconomic convergence

\begin{tabular}{|c|c|c|c|c|c|c|}
\hline & \multicolumn{6}{|c|}{ Period averages } \\
\hline & \multicolumn{2}{|c|}{ euro area } & \multicolumn{2}{|c|}{ UK } & \multicolumn{2}{|c|}{$\begin{array}{c}\text { euro area } \\
\text { unweighted }\end{array}$} \\
\hline & $1989-98$ & 1999-07 & $1989-98$ & 1999-07 & $1989-98$ & 1999-07 \\
\hline Real GDP growth & 2.3 & 2.2 & 2.1 & 2.7 & 2.9 & 3.0 \\
\hline Employment growth & 0.1 & 1.0 & -0.1 & 0.2 & 0.4 & 0.8 \\
\hline Inflation & 3.7 & 2.1 & 3.7 & 1.6 & 4.0 & 2.4 \\
\hline Inflation deviation & 2.0 & 0.6 & 1.8 & 0.6 & 2.4 & 0.8 \\
\hline Fiscal balance & -4.3 & -1.8 & -3.7 & -1.3 & -4.0 & -0.8 \\
\hline Gross public debt & 80.2 & 71.8 & 53.4 & 47.5 & 73.3 & 56.8 \\
\hline Trade balance & 1.0 & 1.6 & -1.1 & -2.2 & 1.7 & 2.9 \\
\hline
\end{tabular}

Source: OECD Data from Holden (2009). Note: inflation deviation refers to the absolute value of annual deviation from the ECB's target of 2 percent. 
Figure 2 - Macroeconomic and international finance indicators for the UK in comparison with the euro area and the US
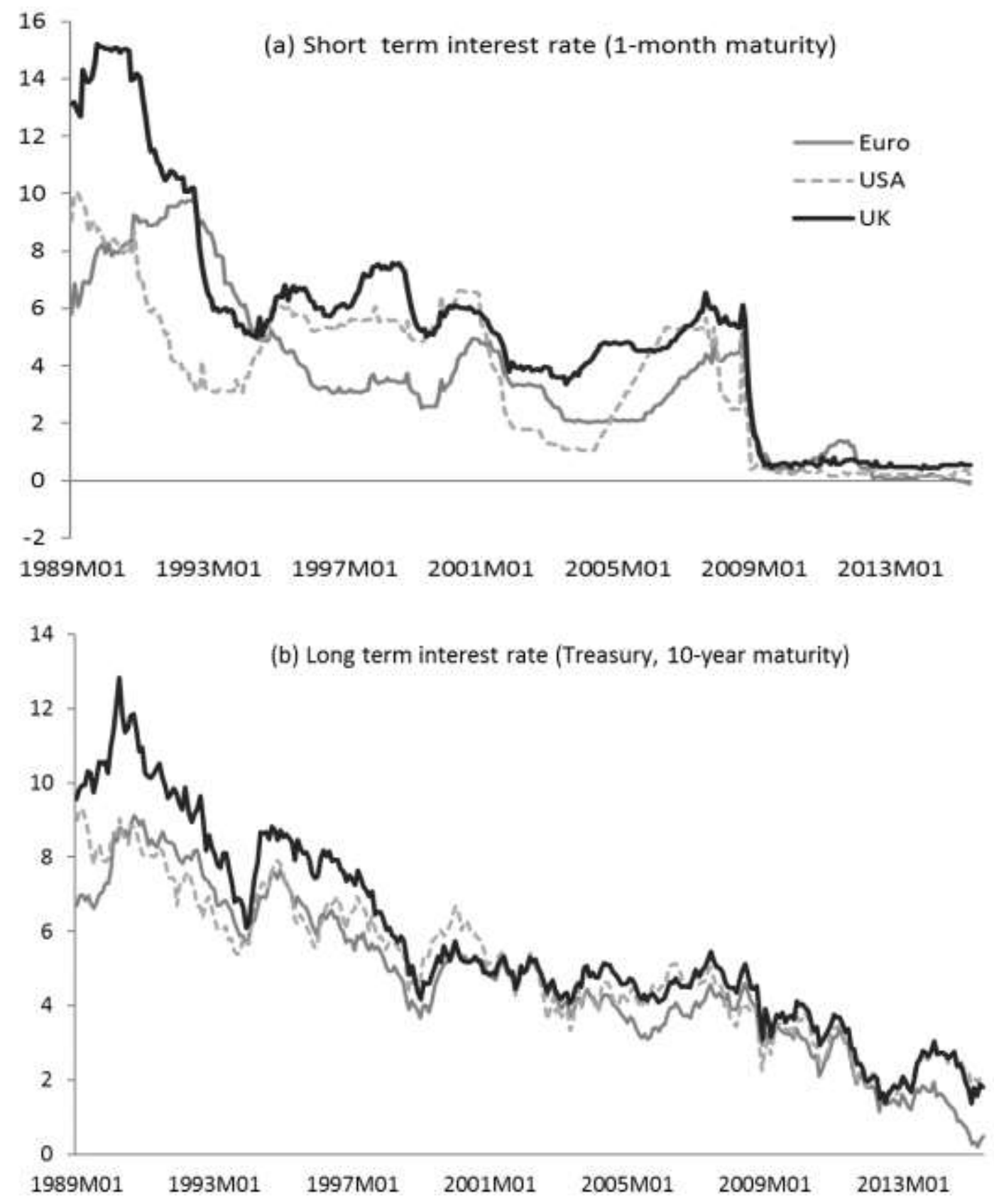

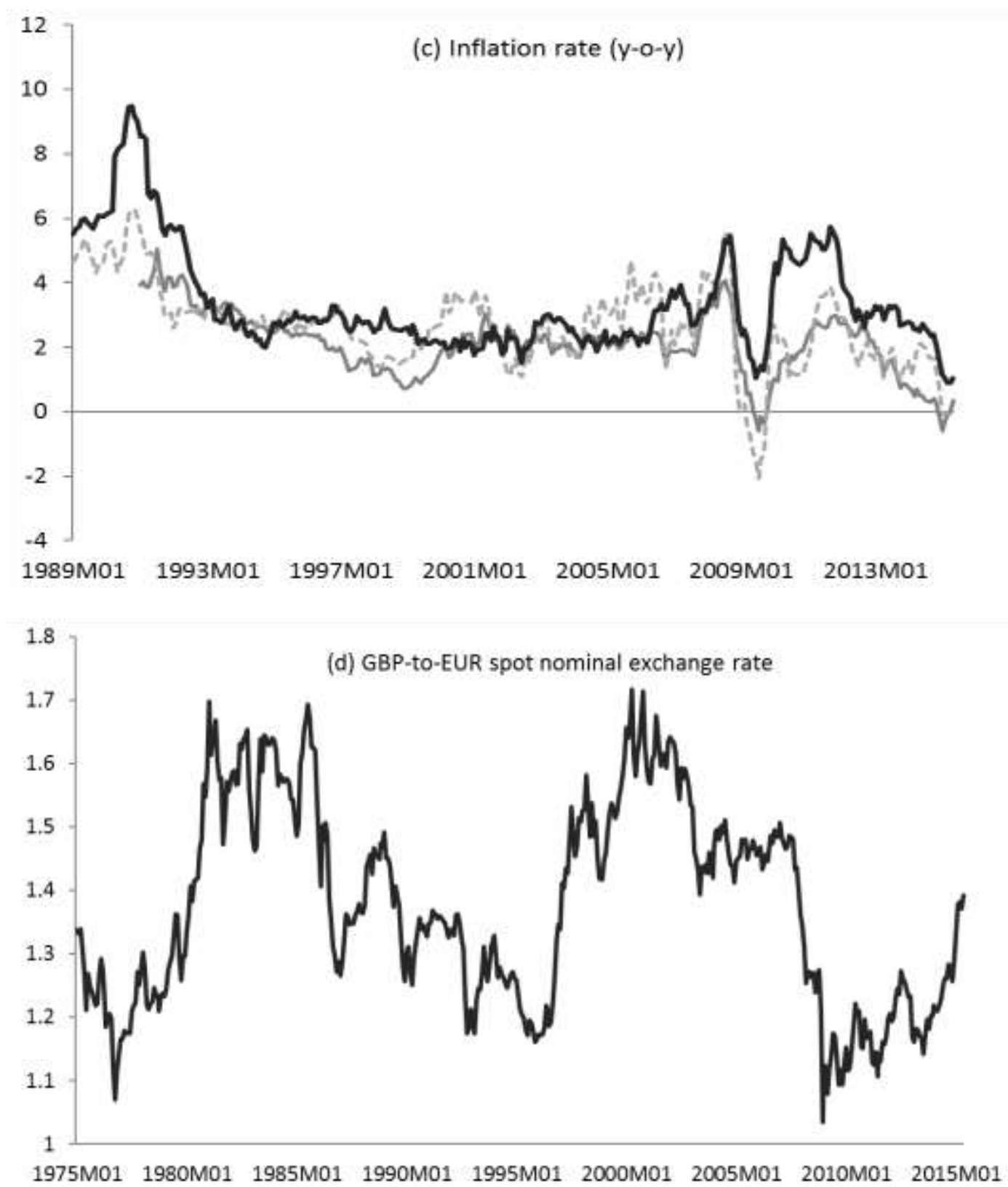

Source: Datastream, BoE, and ECB data. Note: Data for the euro area use ECB's vintage data prior to Jan. 1999 or, for Treasury bonds, Germany's. Last observation is May 2015. 
Figure 3 - The interaction between synchronization and openness

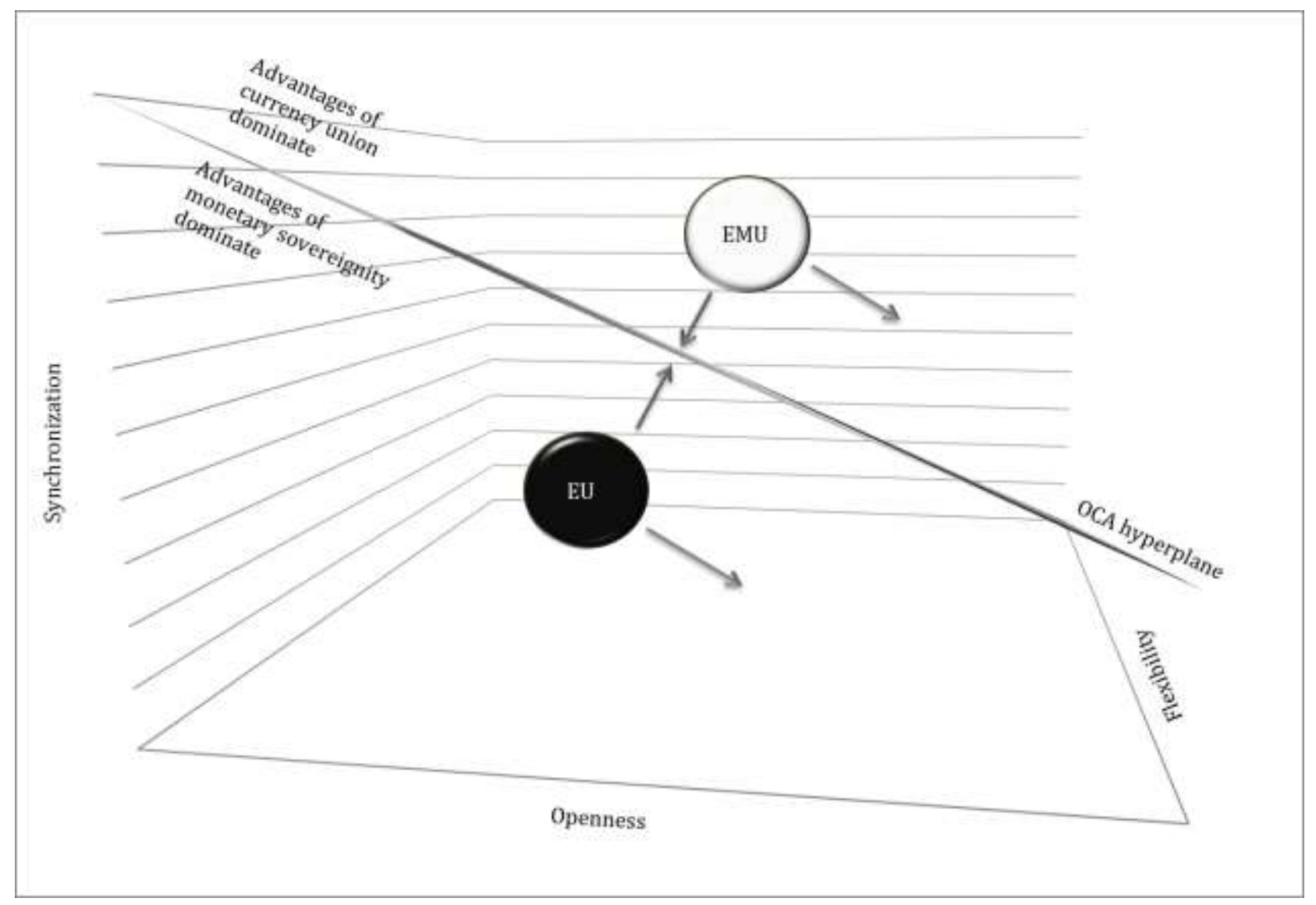

Source: Campos and Macchiarelli (2016a) based on De Grauwe and Mongelli (2005). 
Figure 4 - The UK vs. the Eurozone and the US cycles

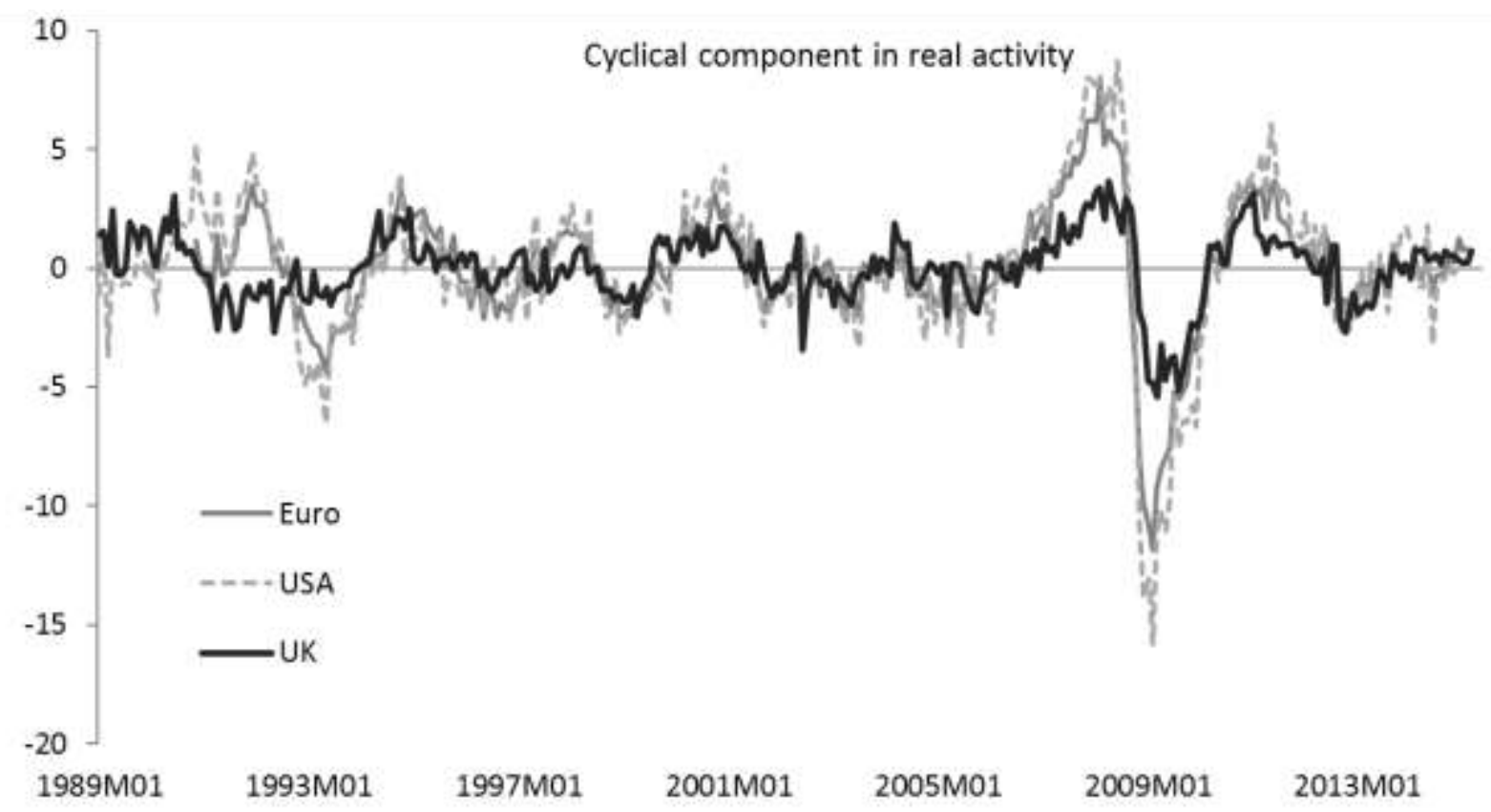

Source: Datastream. Author's calculations. 
Table 3 - Standard deviation and correlation of economic cycles

\begin{tabular}{lccc}
\hline & Jan 1989- Dec 1998 & Jan 1999- May 2015 & Jan 1999- Jul 2007 \\
ST.DEV.(UK) & 1.119 & 1.609 & 1.166 \\
ST.DEV.(EUR) & 1.741 & 2.859 & 1.332 \\
ST.DEV.(US) & 0.918 & 2.105 & 1.306 \\
& & & \\
CORR(EUR,UK) & 0.300 & 0.865 & 0.627 \\
CORR(EUR,US) & 0.291 & 0.872 & 0.604 \\
CORR(UK,US) & 0.508 & 0.786 & 0.511 \\
\hline
\end{tabular}

Source: Datastream. Author's calculations. 
Figure 5 - The role of asymmetries 25 years before and after the EMU

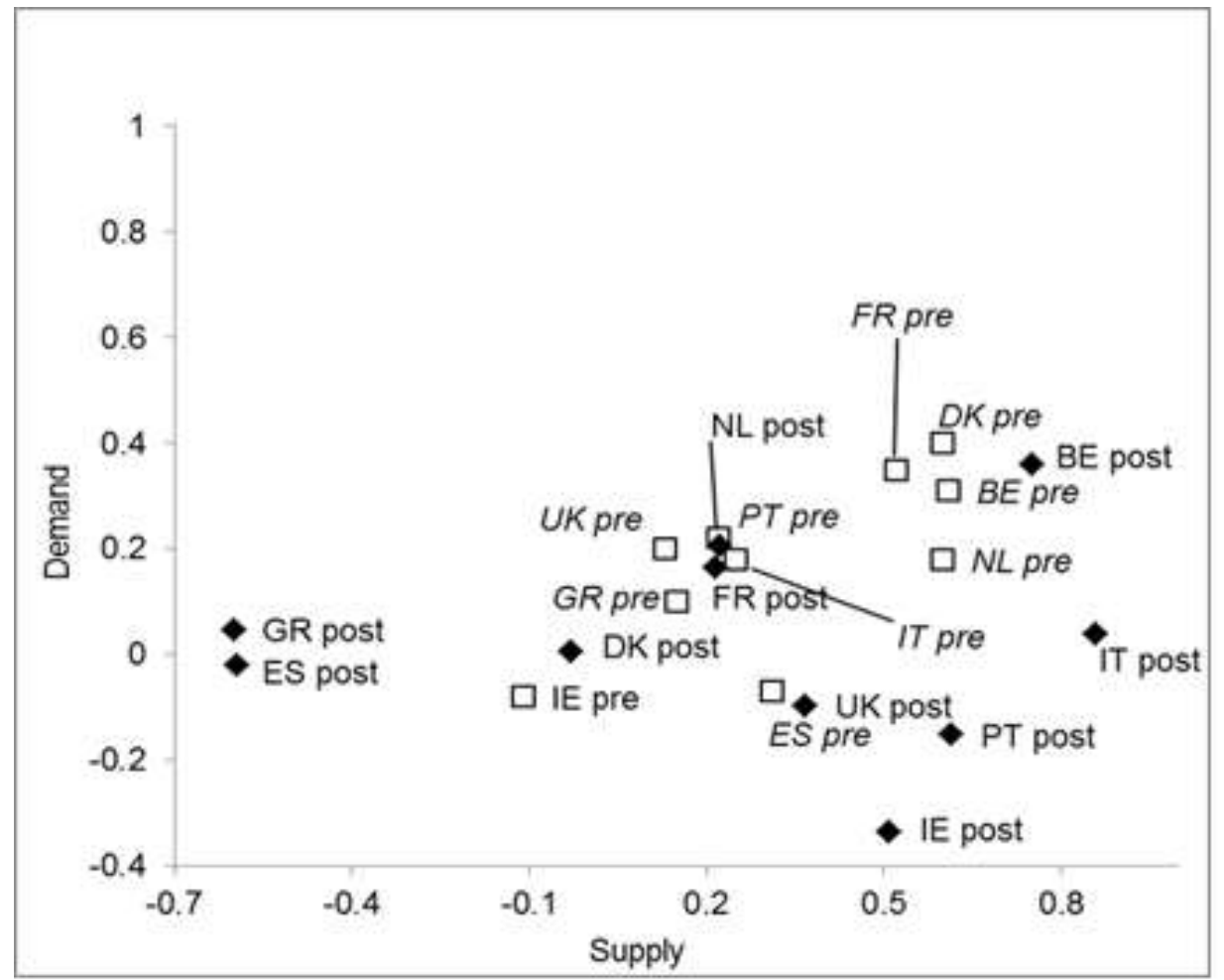

Source: Campos and Macchiarelli (2016b). Note: list of countries - BE = Belgium; DK = Denmark; ES = Spain; FR = France; GR = Greece; IE = Ireland; IT = Italy; NL= Netherlands; PT = Portugal; UK = United Kingdom . The correlation for demand and supply shock is presented with respect to the anchor region ( $\mathrm{DE}=$ Germany). 
Figure 6 - A representation of the crisis 'doom-loop'

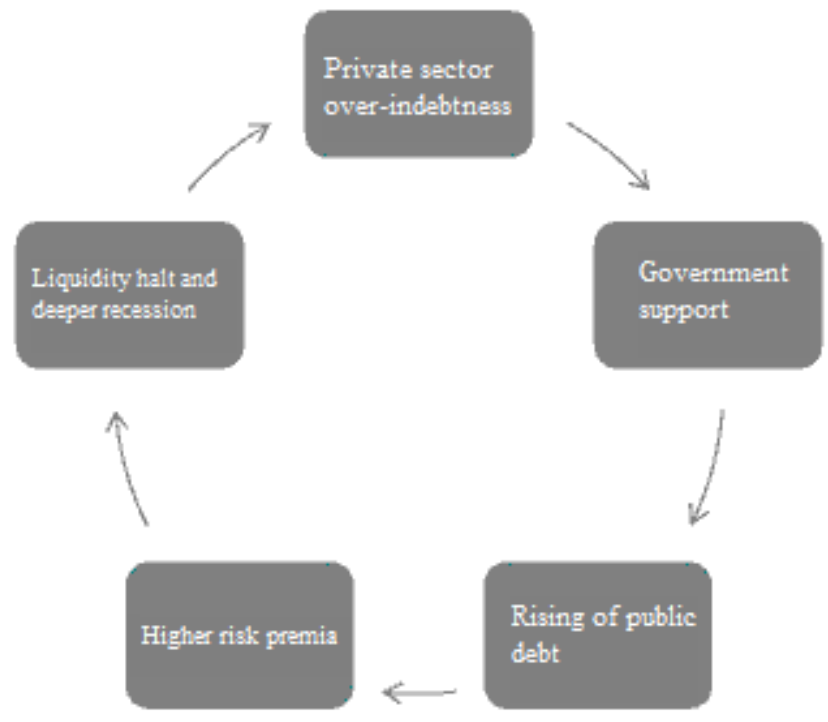

(a)

... and how a 'comprehensive' GEMU would break it

\section{Political Union}
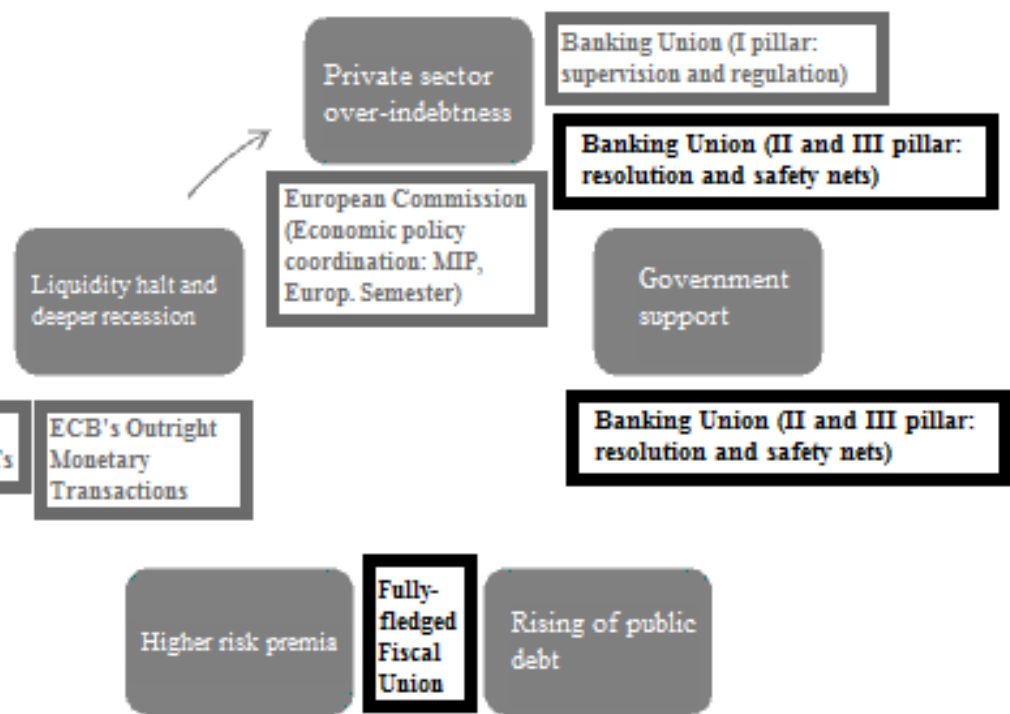

Rising of public

debt

European Commission

(Fiscal surveillance: Fiscal

Compact, 'Six Pack', 'Two

Pack')

(b)

Source: Macchiarelli (2016). Note: The Figure includes the main reforms of the European economic governance framework already in place (grey) and measures not yet in place (black box), as a part of the 5 President Report.

The Figure does not consider measures which are temporary in nature such as unconventional monetary policy. 
Figure 7 - Estimates of costs and benefits of UK's membership of the EU

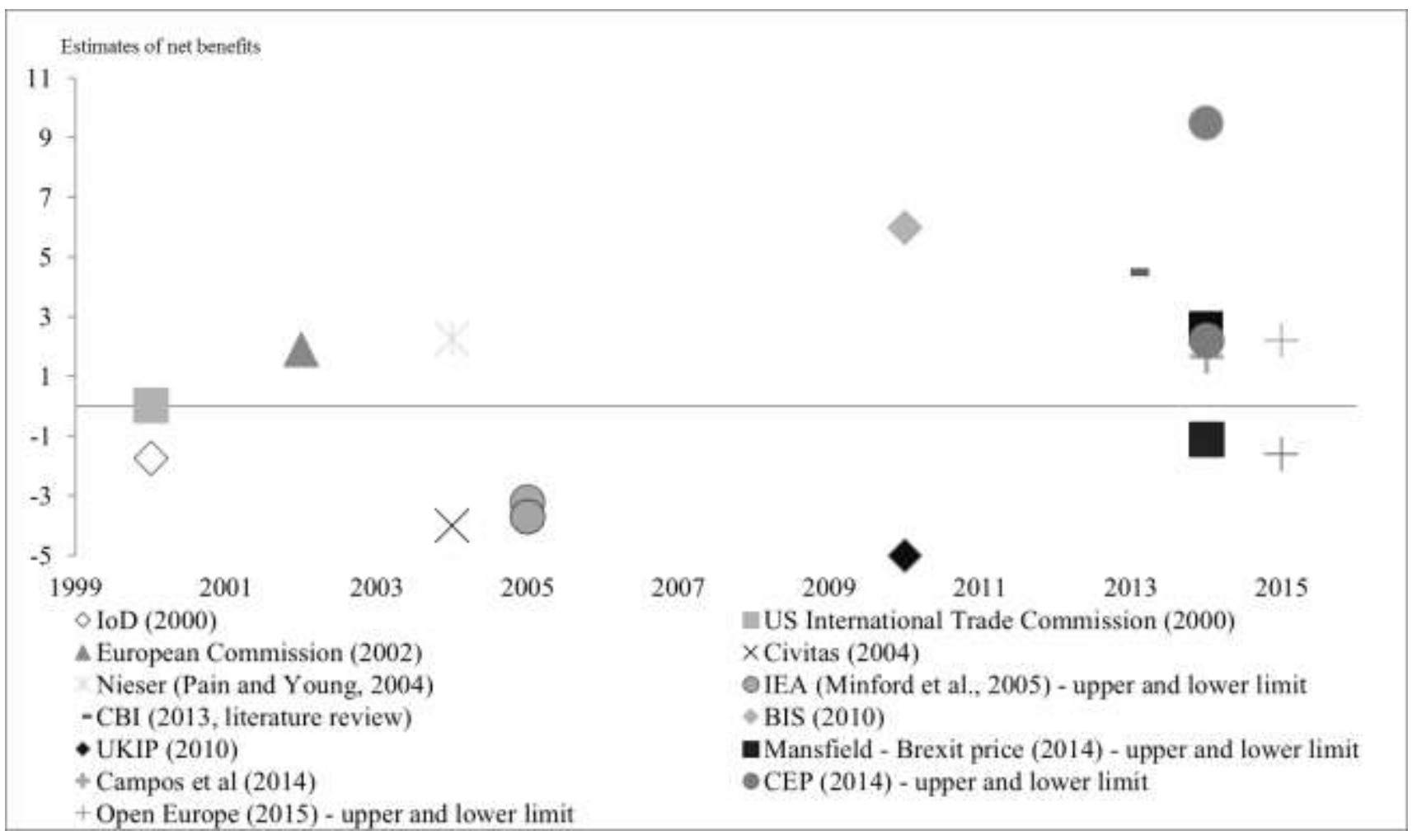




\section{Reference}

Alcidi C., A. Giovannini (2013), 'The ECB dilemma - financial stability or independence?' in "Reconciling Governance and Model: A Five-fold Narrative for Europe", IED and Madariaga-College of Europe Foundation Conference at the European Parliament, 25 April.

Alesina, A. and R. Barro (2002), "Currency Unions", Quarterly Journal of Economics 117(2), pp. $409-436$.

Baun M. J. (1996), "The Maastricht Treaty as High Politics: Germany, France and the European Integration", Political Sciences Quarterly, volume 110, number 4.

Bayoumi, T. and B. Eichengreen (1993), "Shocking Aspects of European Monetary Integration," in F Torres and F Giavazzi (eds.), Adjustment and Growth in the European Monetary Union, Cambridge University Press.

Begg, I. (2014), "Genuine Economic and Monetary Union," in S Durlauf and L Blume (eds.), The New Palgrave Dictionary of Economics, Palgrave.

Butler, G., Jensen, M.D. and Snaith,H. (2016) “"Slow change may pull us apart”: debating a British exit from the European Union', Journal of European Public Policy, pp. 1-7.

Calmfors, L, Driffill, J. (1988), "Bargaining structure, corporatism, and macroeconomic performance," Economic Policy, vol. 6, April, 14-61

Campos, N., Macchiarelli, C. (2016a), “Brexit, ‘euro-ins', and 'euro-outs”, VoxEU.org, 03 March.

Campos, N., Macchiarelli, C. (2016b), "Core and Periphery in the European Monetary Union: Bayoumi-Eichengreen 25 Years Later", Economics Letters, in-press.

Canova, F., C. Ciccarelli and E. Ortega (2005), "Similarities and Convergence in G-7 Cycles", Journal of Monetary Economics 54, pp. 85-878.

Chari V. V., Dovis, A. and P. Kehoe (2015), "Rethinking Optimal Currency Areas", Federal Reserve Bank of Minneapolis, Research Department Staff Report.

Chartered Institute of Personnel and Development (2015), "Employment regulation and the labour market", Policy Report, January.

De Grauwe, P. (1994), "Towards European Monetary Union without the EMS”, Economic Policy, 9(18), pp.149-185.

De Grauwe, P (2016a), Economics of Monetary Union, Oxford University Press, 11th edition.

De Grauwe, P. (2016b), "Why The European Union Will Benefit From Brexit", Social Europe, 24 February. 
De Grauwe, P. and F. Mongelli (2005), "Endogeneities of Optimum Currency Areas: What brings Countries Sharing a Single Currency Closer Together?”, Frankfurt, ECB WP 0468.

De Grauwe, P., and Ji, Y., (2013) 'Self-fulfilling Crises in the Eurozone: An Empirical Test', Journal of International Money and Finance, 34, pp. 15-36.

De Grauwe, P., Ji, Y. (2015), "The Fragility of Two Monetary Regimes: The European Monetary System and the Eurozone", International Journal of Finance \& Economics, 20(1), pp. 1-15.

De la Dehesa. G. (2012), A Self-Inflicted Crisis? Design and Management Failures Leading to the Eurozone Crisis, Occasional Paper No.86, Washington DC: Group of Thirty.

Driffil, J. (2006), “The Centralization of Wage Bargaining Revisited: what have we learnt?” Journal of Common Market Studies, 44, pp. 731-756.

Eichengreen B. and Wyplosz C. (1993), "The unstable EMS”, Brookings Papers on Economic Activities, vol.1993, no.1, pp.51-143.

European Central Bank (2011a), "The Monetary Policy of the ECB”, Frankfurt.

European Central Bank (2011b), "The reform of Economic Governance in the Euro Area - Essential Elements”, ECB Monthly Bulletin Article, March.

Farhi, E. and I. Werning (2015), “Labor Mobility in Currency Unions,” MIT mimeo.

Frankel, J., and Rose, A. (1998), 'The Endogeneity of the Optimum Currency Area Criteria', Economic Journal, 108(441): 1009-25.

Gerba, E., Macchiarelli, C. (2015), "Interaction between monetary policy and bank regulation: Theory and European practice”, LSE Systemic Risk Centre, Special Paper no. 10.

Gerba, E., Macchiarelli, C. (2016), "Policy options and risks of an extension of the ECB's quantitative easing programme: An analysis", Monetary Policy Dialogue, note to the European Parliament, IP/A/ECON/2016-01, Feb.

Giavazzi F. and M. Pagano (1988). "The Advantage of Tying One's Hands: EMS Discipline and Central Bank Credibility”, European Economic Review, 32, pp. 1055-1075.

Glick, R. and A. Rose (2015), "Currency Unions and Trade: A Post-EMU Mea Culpa," NBER Working Paper No. 21535, Sept.

Goodwin, M., Milazzo, C., (2015), "Britain, the European Union and the Referendum: What Drives Euroscepticism?” Europe Programme Briefing, December.

Gros, D. and Schoenmaker, D. (2014), "European Deposit Insurance and Resolution in the Banking Union”, Journal of Common Market Studies, 52(3), pp. 529-546. 
Harding, D. and A. Pagan (2006), "Synchronization of Cycles," Journal of Econometrics 132(1): 5979.

Holden, S. (2009), "The Three Outsiders and The Monetary Union", in SNS, EMU at Ten: Should Denmark, Sweden, and the UK join? (Chapter 6), Stockholm: SNS Förlag.

Hunt J. (2008), "The Economics of German Reunification", (Edited by Steven N. Durlauf and Lawrence E. Blume) The New Palgrave Dictionary of Economics. $\mathrm{n}$

International Monetary Fund (2013), IMF Report on Unconventional Monetary Policies - Recent Experience and Prospects.

Klein, M. W. (1998), "European Monetary Union”, New England Economic Review, March/April, $3(12)$.

Kontopoulos, Y., R. Perotti. (1999). "Government Fragmentation and Fiscal Policy Outcomes: Evidence from OECD Countries." In J. M. Poterba and J. Von Hagen (Eds.), Fiscal Institutions and Fiscal Performance (NBER Conference Report). Chicago: University of Chicago Press, pp. 81-102.

Krugman, P.R. (1993), 'Lessons of Massachusetts for EMU', in: Torres, F., Giavazzi, F. (eds): Adjustment and Growth in the European Monetary Union. Cambridge University Press, Cambridge, 241-261.

Macchiarelli, C., Sangalli, I. (2007), "From EMS to EMU: an obliged passage?", Consortium for Research and Continuing Education in Economics, mimeo.

Macchiarelli, C.., (2016), "European banking union", The New Palgrave Dictionary of Economics, Online Edition. Eds. Steven N. Durlauf and Lawrence E. Blume. Palgrave Macmillan.

McKinnon, R. (1963), “Optimum Currency Area”, American Economic Review, pp. 717-725.

Mongelli, F. (2013), "The Mutating Euro Area Crisis Is The Balance Between "Sceptics" And “Advocates"' Shifting?" Frankfurt, ECB WP 144.

Mundell R. A. (1994), "The European Monetary System 50 Years after Bretton Woods: A Comparison Between Two Systems", Paper presented at Project Europe 1985-95, the tenth edition of the "Incontri di Rocca Salimbeni" meetings, in Siena, 25 November.

Mundell R., (1973), "Uncommon Arguments for Common Currencies", in H.G. Johnson and A.K. Swoboda (eds.), The Economics of Common Currencies, George Allen and Unwin Ltd, London, pp. $114-32$.

Mundell, R., (1961), “A Theory of Optimum Currency Areas”, American Economic Review, pp. 657665 . 
Nechio, F. (2011), "Monetary Policy When One Size Does Not Fit All” , FRBSF Economic Letter 2011-18 (June 13).

Obstfeld, M. (2013), 'Finance at Center Stage: Some Lessons of the Euro Crisis'. CEPR Discussion Paper No. DP9415.

Oliver, T. (2016), "European and international views of Brexit", Journal of European Public Policy, pp. 1-8.

Onorante L. (2007), 'Monetary and Fiscal Policy in a Monetary Union', in 'Monetary Policy, Fiscal Policies and Labour Markets: Macroeconomic Policymaking in the EMU" (edited by R. Beetsma, C. Favero, A. Missale, A. Muscatelli, P. Natale, and P. Tirelli), Cambridge University Press, New York.

Padoa-Schioppa, T. (1999), "Europas Notenbank ist einsam" ("Europe's central bank is lonely"), interview with Die Zeit, 29 December. Padoa-Schioppa, Tommaso (1999), "Europas Notenbank ist einsam" ("Europe's central bank is lonely"), interview with Die Zeit, 29 December.

Peersman, G.; Smets, F. (1999), “The Taylor Rule: A Useful Monetary Policy Benchmark for the Euro Area?" International Finance 2(1), pp. 85-116.

Pesaran H., V. Smith and R. Smith (2007), "What if the UK or Sweden had Joined the Euro in 1999 ? An Empirical Evaluation using a Global VAR," International Journal of Finance \& Economics 12(1): $55-87$.

Pisani-Ferry, J. (2012),' The euro crisis and the new impossible trinity', Brussels, Bruegel Policy Contribution 2012/01, Brussels: Bruegel.

Pisani-Ferry, J. (2013), 'The known unknowns and unknown unknowns of European Monetary Union', Journal of International Money and Finance, 34, pp. 6-14.

Ramey, V. (forthcoming), "Macroeconomic Shocks and Their Propagation", in J Taylor and H Uhlig (eds.), Handbook of Macroeconomics, Volume 2, Elsevier.

Ramiro Troitiño, D. (2016), "The British Position towards European Integration: A Different Economic and Political Approach", Baltic Journal of European Studies, 4(1), pp. 119-136.

Salvatore D. (1997), "The common unresolved problem with the EMS and EMU", American Economic Review, vol.87, n.2, pp.224-226.

Sapir, A., G. Wolff (2016) 'One market, two monies: the European Union and the United Kingdom', Policy Brief 2016/01, Bruegel

Sinn H.-W.(1996), "International Implications of German Unification”, National Bureau of Economic Research (Cambridge), Working Paper n. 5839. 
The Royal Society (2016), "The role of the EU in international research collaboration and researcher mobility, on-line Report.

Valli V. (2002), "L'Europa e l'economia mondiale. Trasformazioni e prospettive”, Carocci Editore, Roma, pp. 100-128.

Velis J.O. (1995), "The collapse of the EMS: Symptomatic of a doomed EMU?", International Conference of the European Community Studies Association, Charleston (SC).

Weber A.A. (1991), "Reputation and Credibility in the European Monetary System", Economic Policy, vol.6, no.12, pp.58-102.

Wyplosz, C., Kostrup, S. (2010), "A Common Pool Theory of Supranational Deficit Ceilings", European Economic Review, 54, pp. 269-278. 